\title{
Paula Coutinho's outstanding contribution to the definition of Machado-Joseph disease
}

\author{
A excepcional contribuição de Paula Coutinho na definição da doença de Machado-Joseph \\ Bruno Carniatto Marques Garcia ${ }^{1}$, Francisco Manoel Branco Germiniani', Paula Marques' ${ }^{1}$, Jorge Sequeiros ${ }^{2}$, \\ Hélio Afonso Ghizoni Teive'
}

\begin{abstract}
Machado-Joseph disease, also known as spinocerebellar ataxia type 3, is the most common form of autosomal dominant ataxia in the world. Paula Coutinho, a highly-regarded Portuguese neurologist worldwide, had a seminal participation in the definition of this disease, more than 40 years ago.
\end{abstract}

Key words: ataxia; spinocerebellar ataxias; Machado-Joseph disease; neurology; history.

RESUMO

A doença de Machado-Joseph, também conhecida como ataxia espinocerebelar tipo 3 (SCA3), representa a forma mais comum de ataxia hereditária autossômica dominante no mundo. Paula Coutinho, neurologista portuguesa de reputação mundial, teve participação fundamental na definição desta doença há mais de 40 anos.

Palavras-chave: ataxia; ataxias espinocerebelares; doença de Machado-Joseph; neurologia; história.

One of the unique opportunities in the life of a physician is to be closely involved in the discovery of a previously-unknown disease. Those who have been involved in the description of the genetics, pathological, clinical and epidemiology aspects of a new condition are very few. Over the past decades, Paula Coutinho, one such person, became acclaimed through her relevant contributions to both Portuguese and international neurology ${ }^{1,2,3}$. Among her remarkable contributions was her extensive study of Machado-Joseph disease (now also incorrectly known as spinocerebellar ataxia type 3, or SCA3), the most common spinocerebellar ataxia in the world ${ }^{1,2,3}$. This paper presents the most relevant neurology contributions from Paula Coutinho, in particular in her description of Machado-Joseph disease.

\section{PAULA COUTINHO - A SHORT BIOGRAPHY}

Paula Coutinho was born in Macieira de Cambra (Aveiro, Portugal), in 1941 (Figure 1). She received her medical degree from the Faculty of Medicine, University of Porto, in 1966. By then, she was already an attending in the neurology service at the Geral de Santo António Hospital, Porto, created and directed by the internationally-respected Professor Corino Andrade ${ }^{1,4}$. In the early 1970s, she became an assistant in neuropathology at the Geneva University, and later Chief Clinical Officer at the Geneva University Neurology Clinic. After returning to Portugal, she was responsible for clinical neurology at the "Centro de Estudos de Paramiloidose", from 1975 to $1992^{4}$. She was head of the Neurology Service, at Hospital Geral de Santo António, from 1977 to 1998. During that period, she participated in the definition of a novel neurological disorder, Machado-Joseph disease, in which she became the main world researcher. She has also collaborated in drafting and structuring the teaching of neurology at the new Instituto de Ciências Biomédicas (Institute of Biomedical Sciences) Abel Salazar (ICBAS) at the University of Porto, from 1980 to $1997^{4}$. She completed her PhD in Medicine (Neurology) at ICBAS, in 1992, with a thesis entitled "Machado-Joseph Disease: Essay of Definition"1 (Figure 2). She was also the director of the Department of Medicine at the Hospital de São Sebastião, Feira, Portugal,

\footnotetext{
${ }^{1}$ Universidade Federal do Paraná, Hospital de Clínicas, Unidade do Distúrbios do Movimento, Departamento de Medicina Interna, Serviço de Neurologia, Curitiba PR, Brasil;

${ }^{2}$ Instituto de Biologia Molecular e Celular (IBMC), Instituto de Investigação e Inovação em Saúde (i3S); e Instituto de Ciências Biomédicas Abel Salazar (ICBAS), Universidade do Porto, Porto, Portugal

Correspondence: Hélio A. G. Teive; Rua General Carneiro, 1103/102, Centro; 80060-150 Curitiba PR, Brasil; E-mail: hagteive@mps.com.br

Conflict of interest: There is no conflict of interest to declare.

Received 11 July 2017; Accepted 13 July 2017.
} 
and a clinical neurologist and researcher in the Unit for Genetic and Epidemiological Research in Neurological Diseases and the Centre for Predictive and Preventive Genetics (www.cgpp.eu) at the Institute for Molecular and Cell Biology (www.ibmc.up.pt), now integrated into the Instituto de Investigação e Inovação em Saúde (Institute of Research and Innovation in Health) (i3S, www.i3s.up.pt) of the University of Porto, Portugal ${ }^{4}$.

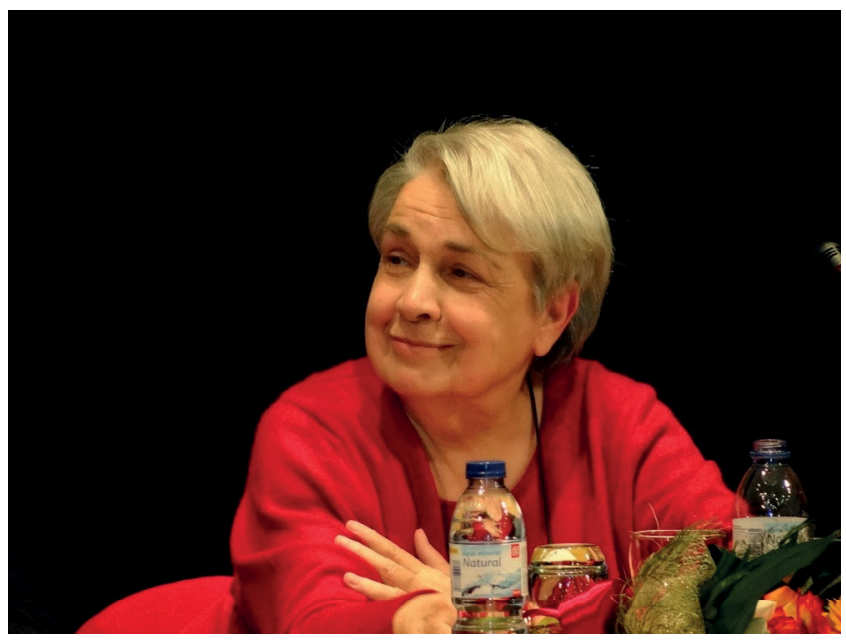

(Courtesy of Professor Jorge Sequeiros).

Figure 1. Professor Paula Coutinho (1941- ).

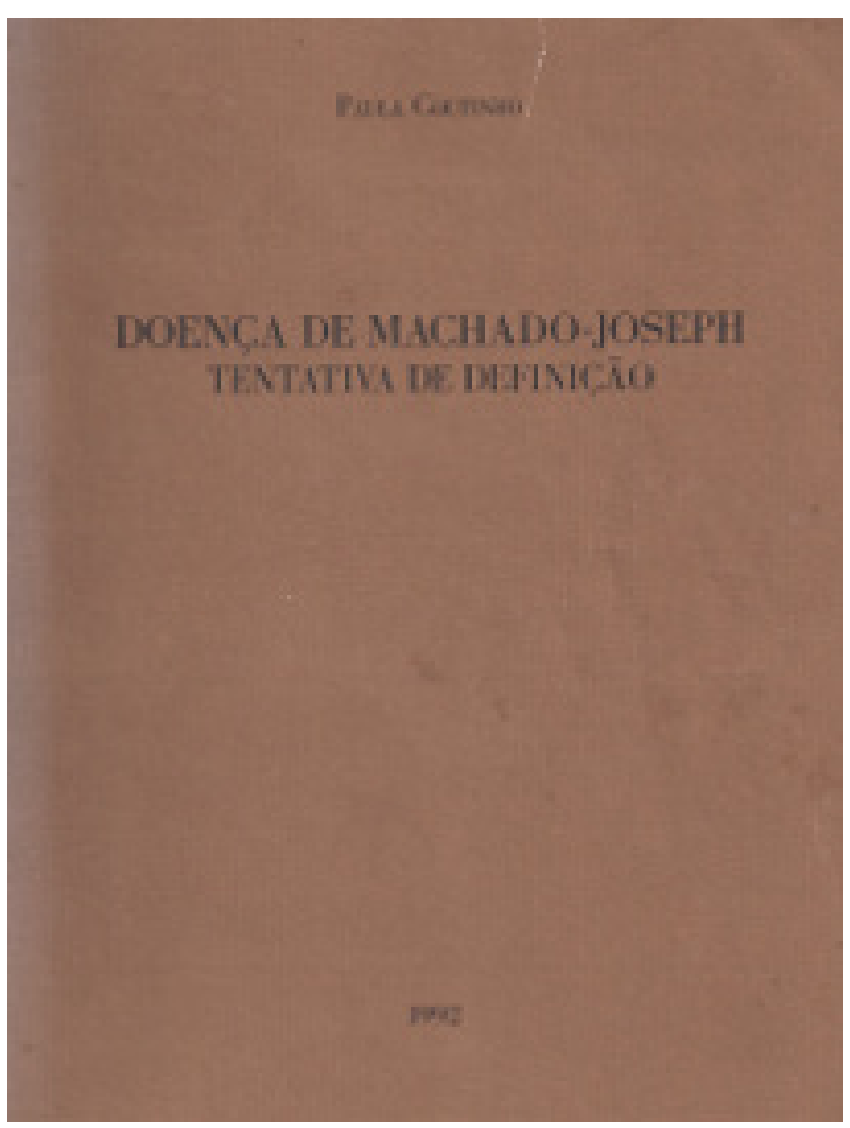

Figure 2. Paula Coutinho's thesis - 1992.
COUTINHO'S OUTSTANDING CONTRIBUTION TO THE STUDY OF MACHADO-JOSEPH DISEASE

In the 1970s, families with hereditary ataxia, originating from the Portuguese islands of the Azores, were described in the United States ${ }^{1,2,3,4,5}$. Then, in 1975, the Portuguese Director-General of Health asked Corino Andrade (renowned for having investigated and first described familial amyloid polyneuropathy) to travel to the Azorean Islands and examine local families known to be affected by similar diseases to those being described in the USA ${ }^{1,2,3}$. Corino Andrade invited Paula Coutinho to go with him on this research trip ${ }^{1,4}$. Coutinho was the first to propose that the Machado, Thomas and Joseph families actually had the same new genetic condition, but with a somewhat different phenotypical presentation $^{1,2,3,5}$. After reviewing all cases observed in 15 families from the Azorean Islands, in 1978, with Corino Andrade, Coutinho defined for the first time the clinical characteristics of the disease, further classifying it into subtypes, which helped improve the diagnosis and prognosis of this disorder $^{1,3}$. In 1980, she proposed the name Machado-Joseph disease (MJD) for this condition (Machado being the first family described, and Joseph being the largest and better-studied family) 5 . From 1978, she began finding the first mainland Portuguese families and defined the diagnostic criteria for MJD ${ }^{5}$. Later on, in 1992, she refined these in her $\mathrm{PhD}$ thesis ${ }^{1}$, as well as described the phenotype and evolution of three major sub-phenotypes (which she called types 1, 2 and 3). Coutinho was the first to highlight the value of neuro-ophthalmological signs for a precise diagnosis of MJD (external progressive ophthalmoplegia) ${ }^{1}$. Among other ocular abnormalities are bulging eyes (due to eyelid retraction), and horizontal and vertical nystagmus ${ }^{1}$. She also showed that the "peripheral neuropathy" described in the Machado family was, in fact, due to peripheral signs. Coutinho also described a child who began manifesting symptoms at the age of eight and who had died by the age of $15^{1}$. This case study offered a better insight of the clinical progression of MJD, but mainly contributed to the understanding of the brain regions most affected by the neurodegenerative process, thus confirming that MJD was a new type of hereditary ataxia ${ }^{1}$. Coutinho also kept a friendly, though lively, dispute with Anita Harding for several years, about the classification of dominant ataxias, insisting on the fact that, under some circumstances, MJD could be distinguished from other dominant forms on clinical grounds alone. This enabled Paula Coutinho to propose the clinical diagnosis of MJD in several families previously described in the scientific literature (all later proven by molecular genetic testing), including the Drew family of Walworth, who were followed by Harding in the UK. ${ }^{6}$ Coutinho contributed to the MJD gene mapping efforts ${ }^{7}$ and established the correlation between the clinical manifestations and the size of the (CAG)n expansion, providing a new perspective into the pathophysiology of the disease, and allowing insights 
to be drawn for other polyglutamine disorders ${ }^{8}$. Moreover, she contributed to a worldwide study by finding two independent mutational events (Joseph and Machado), tracking the ancestral origins of the Joseph lineage to Asia and showing it to be over 7,000 years old ${ }^{9}$. Paula Coutinho also conducted a systematic population-based epidemiological survey of hereditary ataxias and spastic paraplegias in Portugal, for over 12 years. This is still an unparalleled study that, apart from improving knowledge of these diseases in the country, led to the clinical and genetic identification of several new forms of recessive (AOA1, AOA2, AOA4) and dominant ataxias (SCA37), as well as several new loci and genes for spastic paraplegias ${ }^{10}$.

\section{CONCLUSION}

Coutinho's life and the history of Machado-Joseph disease are very much intertwined. Most of today's knowledge about this neurological disorder, among others, is due to her early efforts and tireless investigations in several levels of research ${ }^{1,2,3,5,7,8,9,10}$.

\section{References}

1. Coutinho P. Doença de Machado-Joseph:Tentativa de definição (Tese). Porto, Universidade do Porto; 1992

2. Coutinho P, Calheiros JM, Andrade C. Sobre uma nova doença degenerativa do sistema nervoso central transmitida de modo autossómico dominante e afectando famílias originárias dos Açores. O Médico. 1977;82:446-8.

3. Coutinho P, Andrade C. Autosomal dominant system degeneration in Portuguese families of the Azores Islands. A new genetic disorder involving cerebellar, pyramidal, extrapyramidal and spinal cord motor functions. Neurology. 1978;28:703-9.

4. Prémios Santa Casa Neurociências. Professora Dra. Paula Coutinho (S.P. Neurologia). Santa Casa de Misericórdia. Lisboa, Portugal, 2017 [acess 2017 July 4]. Available from: http://www.scml.pt/ ptPT/premios_santa_casa_neurociencias/premios_santa_ casa_neurociencias/orgaos/juri/professora_doutora_paula_ coutinho__S_P__neurologia_/

5. Lima L, Coutinho P. Clinical criteria for diagnosis of Machado-Joseph disease: report of a non-Azorean Portuguese family. Neurology. 1980;30(3):319-22. https://doi.org/10.1212/WNL.30.3.319
6. Giunti P, Sweeney MG, Harding AE. Detection of the Machado- Joseph disease/spinocerebellar ataxia three trinucleotide repeat expansion in families with autosomal dominant motor disorders, including the Drew family of Walworth. Brain. 1995;118(5):1077-85.

7. Sequeiros J, Silveira I, Maciel P, Coutinho P, Manaia A, Gaspar C et al. Genetic linkage studies of Machado-Joseph disease with chromosome 14q STRPs in 16 Portuguese-Azorean kindreds. Genomics. 1994;21(3):645-8.

8. Maciel P, Gaspar C, DeStefano AL, Silveira I, Coutinho P, Radvany J et al. Correlation between CAG repeat length and clinical features in Machado-Joseph disease. Am J Hum Genet 1995;57(1):54-61.

9. Martins S, Calafell F, Gaspar C, Wong VC, Silveira I, Nicholson GA et al. Asian origin for the worldwide-spread mutational event in Machado-Joseph disease. ArchNeurol. 2007;64(10):1502-8. https://doi.org/10.1001/archneur.64.10.1502

10. Coutinho P, Ruano L, Loureiro JL, Cruz VT, Barros J, Tuna A et al. Hereditary ataxia and spastic paraplegia in Portugal: a populationbased prevalence study. JAMA Neurol. 2013;70(6):746-55. https://doi.org/10.1001/jamaneurol.2013.1707 